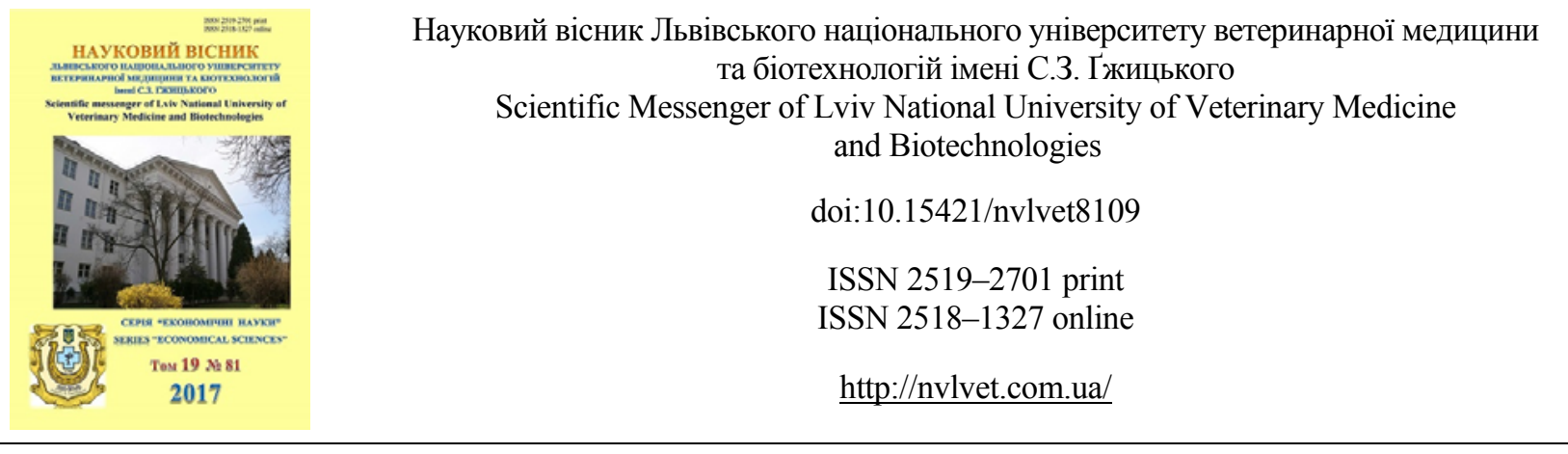

UDC 332: 334: 338: 339: 658

\title{
Entrepreneurship in agriculture
}

\author{
I.B. Smolynets, I.R. Olenych, I.I. Hariv, B.V. Gutyj \\ smolinecz86@mail.ru \\ Stepan Gzhytskyi National University of Veterinary Medicine and Biotechnologies Lviv, \\ Pekarska Str., 50, Lviv, 79010, Ukraine
}

\begin{abstract}
The modern development of industrial associations is characterized by the use of such legal forms, which preserve the main characteristics of the family farm and at the same time create favorable conditions for the organization of production structures, adequate to large enterprises, family transfer farms. It is these trends in the formation of entrepreneurial activity in agriculture taking into account domestic realities should be taken into account in developments on the restructuring and transformation of domestic agricultural production. Typical farmer, even when he has a small family farm, combines investor, manager and manager in it. In somewhat larger structures, such as family farms, maybe also an accountant, an organizer of work, a specialist in the care of plants and animals, a mechanic, etc. On a successful business, in our view, we can say if: the enterprise has income to pay all necessary expenses; the company has additional income necessary to pay the loans that may be invested; the productive capacity of the enterprise and its potential are not diminished, but desirable - they are developing. Compliance with these conditions can be one of the important reasons for the successful development of entrepreneurial activity. Despite certain advantages or disadvantages of individual forms of entrepreneurial activity, it is necessary to develop various organizational and legal forms in agriculture in market competitive conditions. But it should be borne in mind that social changes affect the system of organizational-economic and legal relations in agriculture. Subjects of entrepreneurial activity who are managing today in agriculture, functioning on the basis of different forms of ownership, not only have the right to exist, but also, competing with each other, create conditions for the development of market relations, profitable agricultural production.
\end{abstract}

Key words: agriculture, entrepreneurial activity, agrarian production, market

\section{Citation:}

Smolynets, I.B., Olenych, I.R., Hariv, I.I., Gutyj, B.V. (2017). Entrepreneurship in agriculture. Scientific Messenger LNUVMB, 19(81), 56-63.

\section{Introduction}

The development of entrepreneurial activity in our country began in the context of reforming and developing market relations and continues to occur in conditions of constant complication of agricultural production and the economic environment within the country and against the background of increasing globalization of the world economy. Actually, such conditions of world development have led to the intensive development of economic processes and determined the objective need for adaptation of entrepreneurial activity in agriculture to the new conditions of management due to the considerable limited resource potential of each economic entity. Global changes in the business environment that have taken place in recent years, encourages business entities to pursue a survival policy in such complex conditions of competition at the expense of activating the internal potential, improving the organizational and economic mechanism and improving the relationship between the participants in the production process.

Reforming of socio-economic relations in agricultural production and the agrarian sector of the economy is objectively linked with the revival and development of entrepreneurial activity. In entrepreneurial activity, there are great opportunities for improving organization and improving the efficiency of agricultural production, which is determined by the economic nature and its essence as an important organizational form of economy.

It is determined that the essence of entrepreneurial activity in agriculture is to organize the production process by the means of production and labor and the use of human resources and resources of the natural environment, the main of which is land, in order to obtain agricultural products of the proper quality and ensure the efficiency of its production. The economic feature of this activity is the possession or use of available resources, in particular land, skillfully combined with rational use, 
where the sale of agricultural production would provide economic entities with appropriate financial income. In this case, entrepreneurial activity is considered and interpreted as a commercial activity in agriculture in order to profit.

An important role of entrepreneurial activity in agriculture is proved. in particular in the performance of its functions: economic, stimulating and social, which consist in providing the population with agrarian products, livestock - feed, increase of employment of the population, in particular, rural, development of the agrarian market and infrastructure of the agrarian sector.

Peculiarities of agrarian production, different conditions of economic activity, the purpose of the activity and its functions are determined by the existence of various forms of sub-activity in agriculture. The variety of functions of agrarian production with regard to the methods of managing, providing food, different needs for raw materials, connection with the agrarian market, a different opportunity to provide resources and different needs in them on the production of specific types of agricultural products, adaptation to different natural and economic conditions, traditions and customs, social aspects are of particular importance.

In the aspect of development, entrepreneurial activity in agriculture by ownership forms includes: individual farms, private farms, households, peasant farms, private and public agricultural enterprises, collective farms, in particular peasant unions, agricultural companies, interfarm enterprises and associations of various kinds and types of society, which are divided by form of association and level of responsibility, form of ownership, size and specialization.

\section{Results and discussion}

The correct definition of a particular business model allows for a more accurate assessment and design of a modern and promising strategy for the activities of business entities. As the scientist Yu.E. Gubeni notes, according to the object of entrepreneurship distinguish types of entrepreneurship that characterize the direction and object of entrepreneurial activity. The oldest and often - the most widespread type of business, as we have already mentioned, is trade - a kind of commercial entrepreneurship. As a matter of fact, the formation of entrepreneurship began as a kind of human activity (Gubeni, 2001). Types of entrepreneurship may include:

- productive (production, provision of services, their realization);

- commercial (commodity-money, financialexchange operations);

- intermediary (business contact and partnership with other enterprises);

- financial (financial, monetary and credit operations);

- insurance (insurance operations);

- insurance (insurance operations);

- information and consulting (informational services, consulting, external management, sanation, etc.);
- $\quad$ service (provision of various non-productive services).

Modern technological and technical solutions in the fields of construction, engineering, information technology, recreation, processing and storage of agricultural products, biotechnologies, energy saving, etc. provide new opportunities in the development of entrepreneurship (Gubeni, 2001).

To date, legal provision of types and principles of economic activity of various forms of entrepreneurial activity in the agrarian sector has been created. The main legislative acts of Ukraine on business development are the Constitution, Commercial and Commercial Codes, Laws: «On Entrepreneurship», «On Property», «On Enterprises in Ukraine», «On Business Associations», «On Investment Activity», «On Economic Competition», «On Foreign Economic Activity», «On Bankruptcy», «On Banks and Banking», «On Patenting of Certain Types of Entrepreneurial Activity», «On Commodity Exchange», «On Leasing» and others. The most important legislative acts, which must be familiarized with the future entrepreneur, are the Laws: «On State Registration of Legal Entities and Individuals - Entrepreneurs», «On Entrepreneurship», «On Business Associations», «On Bankruptcy», «On joint stock companies» (Gubeni, 2001).

Land Code of Ukraine and laws are important regarding entrepreneurship in agriculture: «On the peasant economy», «On the farm economy», «On Collective Agricultural Enterprise», «On Agricultural Co-operation», «On Land Payments», «On Priority of Social Development of the Village and the Agro-Industrial Complex in the National Economy», «On the Privatization Features of property in the agro-industrial complex» and others.

Significant role in stimulating the development of entrepreneurship in the countryside was played by the Presidential decrees «On Measures to Reform the Agrarian Relations», «On Non-Settle Measures to Accelerate the Reform of the Agrarian Sector of the Economy» and others.

In recent years, the legal framework has been supplemented with new normative documents, including the Laws of Ukraine «On State Support to Agriculture in Ukraine», «On Amendments to certain Laws of Ukraine on Improving the Mechanisms of State Regulation of the Agricultural Market», «On Agricultural Cooperatives», «On Agricultural Advisory Activities», «On Veterinary Medicine», «On protection of the rights of buyers of agricultural machines», «On the system of engineering and technical support of the agro-industrial complex of Ukraine», «On wholesale markets for agricultural products».

In the special Law of Ukraine «On the Basic Principles of the State Agrarian Policy for the Period till 2015» the strategic objectives of such a policy are defined: guarantee of food security of the state; preservation of the peasantry as a bearer of the Ukrainian identity, culture and spirituality of the nation; integrated development of rural territories and solving of social problems in rural areas.

It is regulated the outlined questions and a number of decrees of the President of Ukraine, resolutions of the 
Cabinet of Ministers of Ukraine and various state (national) programs for the development of domestic agriculture and rural areas.

The legislative base of entrepreneurship in Ukraine is imperfect and unstable. Its particular disadvantage, which will have strategic consequences - incomplete compliance with European norms and requirements, not adaptation to EU principles and norms. Separate legislation contradict each other. Therefore, there is a need for the urgent development of legislation, its filling with new laws, norms, requirements, with simultaneous systematization, with the adherence to the requirements of international agreements, norms, rules officially recognized or ratified by Ukraine.

In accordance with legal regulation, there are various forms of entrepreneurial activity in agriculture. The state classification of Ukraine, the organizational and legal form of entrepreneurial activity is recognized as a form of economic (in particular, entrepreneurial) activity in agriculture with the appropriate legal basis, which defines the nature of the relationship between the founders (participants), the regime of property responsibility for the obligations of the enterprise (organization), the procedure for the creation, reorganization, liquidation, management, distribution of received profits, possible sources of funding activities, etc. (Olenych et al., 2012; Olenych et al., 2013; Smolynets et al., 2016).

In our opinion, the most successful in the scientific sense is the definition of the subject of entrepreneurial activity in agriculture as an organizational form of farming, due to the existing socio-economic structure and qualitative characteristics such as ownership, organizational structure of economic structures, economic relations etc.), which determine the specifics of the existence of some of them. So, the form of entrepreneurial activity in agriculture is the most typical organizational characteristic of business entities with the listed characteristics. Business entity - is a separate specific production unit that carries out economic activity in agriculture. Accordingly, economic entities may belong to certain forms of entrepreneurial activity.

Today, in modern conditions of market relations, organizational forms of entrepreneurial activity in agriculture are based on different forms of ownership, which is the basis of their identification. Scientists' opinion that in the agrarian sector of the Ukrainian economy there are enterprises which operate on the private, collective, economic, communal, state basis of management can be partially agreed. However, in our opinion, these forms of ownership are essential for the functioning of certain business entities, but not the only ones.

By forms of ownership, organizational and legal forms of entrepreneurial activity in agriculture can be divided into private enterprises and agricultural companies, where entrepreneurial relations are formed on the basis of private property, peasant associations of shareholders, where entrepreneurial activity is based on a collective ownership form and state agrarian enterprises, the basis of which was formed by state agrarian enterprises.

Type of enterprise by nature of ownership shows the economic nature of entrepreneurial activity in agriculture.
The principles of organization and functioning are determined by the organizational form-type of such an enterprise.

Such a variety of forms of ownership and predetermines various entrepreneurial activities in agriculture and its form predetermines, that none of them can be recognized as ideal, and accordingly the best from the point of view of the optimal combination of interests of the owner of land and society.

Agricultural producers in the agricultural sector can be divided according to various criteria. The traditional structural typology can be the most common here: the size of the economy or enterprise (in terms of the area or value of produced or sold agricultural products), the share in agricultural production, the forms of ownership, the production specialization, the characteristics of the persons conducting the economy and the geographical location. Furthermore, forms of entrepreneurial activity in agriculture may differ in the way of management, development strategies, the formation of the economy of agricultural production, and others.

The classification of organizational and legal forms of entrepreneurial activity in agriculture by organizational and legal basis includes agricultural enterprises, farms and households.

Sufficiently acceptable and, from a scientific point of view, a good classification of forms of entrepreneurial activity in agriculture, proposed by O. Rozkoshna:

- individual forms, formed on the basis of private ownership, with the subsequent possible use of lease business relations (farms, private enterprises, households);

- share forms, where in the overwhelming majority of which the economic basis is the shareholding (joint-stock companies);

- collective forms that are formed and exist on the basis of a combination of such state or private ownership on the means of production,

- in particular, land and property with collective forms of entrepreneurial activity (collective agricultural enterprises, agricultural companies, etc.) (Olenych et al., 2011).

According to the classification and separation of the State Statistics Service of Ukraine, agricultural enterprises and households are the main categories of farms in the agricultural sector. The division of agricultural enterprises into organizational-legal forms and forms of ownership shows a large variety of them in the agrarian sector.

The main ones are: state-owned agricultural enterprises, collective farms, industrial agricultural cooperatives, agricultural companies, private enterprises, economic partnerships, joint ventures and agricultural holdings. All of them as a form of entrepreneurial activity differ in some way and have distinctive features (form of ownership, organizational and management structure, legal basis, etc.).

The theory of entrepreneurship and enterprise is sufficiently widely elucidated in the economic literature, in particular in the works of classics and modern national agricultural literature. Without resorting to separate classical and modern approaches due to their essence, 
which became axiomatic, we must note that directly related to the subject-matter of the research.

Entrepreneurship is quite a multifaceted concept common in various sectors of the economy. It is inappropriate to identify it only with the purchase and sale of goods, or with normal commercial or commercial activity. The concept of entrepreneurship is much wider. This is not only a special kind of activity, but a set of relations that arise in the course of its implementation. Therefore, entrepreneurial activity can be considered on various features. Accordingly, modern approaches to the classification of businesses are ambiguous. This leads to the need for further study of this issue to identify the conditions for the effective development of all types of entrepreneurial activity in the agrarian sector (Smolynec and Garasymljuk, 2014).

Transformation processes in the agrarian sector of Lviv region created the prerequisites for the formation of organizational and legal structures and the revival of private entrepreneurship. On the basis of former collective farms and state farms, new business entities were created on the basis of private property. Using the material and technical base of agricultural enterprises, farming are formed at the initial stage. New business entities have smaller land plots. In many cases, farms were formed as a result of the division of collective agricultural enterprises into shares of their owners. Some of the lands went away to the use of farmers, and part of the land units joined the property of former personal subsidiary farms, (today the economy of the population).

Enterprise, in agricultural production is the main economic component. A business entity specializing in the production of certain goods, in particular agricultural products, may be called the enterprise. Enterprises together with households are the main subjects of agricultural production.

We believe that an enterprise should be understood as an organizational unit that has economic, organizational and legal differences, which has economic, organizational and legal differences, with a special combination of material and non-material factors, created for the purpose of commodity production or provision of services through an increase in their volume and improving product quality by maximizing profits and interoperability and ensuring competitiveness. An agricultural enterprise is an independent statutory object with the right of a legal entity to carry out production activities in the field of agriculture in order to obtain the corresponding profit (income).

The enterprise is constantly forced to decide what production to produce, in what quantities and under what conditions and use of which factors of agricultural production. The process of implementing the choice itself in conditions of limited or affordable resources - this is the appropriate process of management, and individuals that make decisions in this activity are called business entities. So, we can assume that to some extent the essence of management is the process of making certain manufacturing decisions.

In the concept of «enterprise», three of the following components: economic, organizational and legal can be distinguished. An economic feature of an enterprise or entrepreneurial activity is in the possession or use of available resources, skillfully combining them and rational use. Organizational feature is the presence of the name, organizational structure, estate, physical limits, autonomy of activity. Legal feature means the ability of an enterprise to operate in agriculture in accordance with legal norms and acts.

The modern environment in which enterprises are located indicates that it must be both global and local, centralized and decentralized, large and small, wellplanned and elastic. The enterprise must produce agricultural products in accordance with the needs of buyers and consumers, not forgetting about the market niches, adhere to the standards and requirements of consumers, and at the same time it should be profitable. All this determines the parameters of the activity of the agricultural enterprise and its types.

A common feature of such agricultural enterprises, regardless of the organizational and legal form, which distinguishes them among other production structures of this industry, is the direction of entrepreneurial activity in agriculture for the receipt of profits, and in the case of long-term loss-making is minimized. This is how they differfrom such forms of agricultural production in our country today as the economy of the population. The main purpose of functioning of the overwhelming majority of such households is to provide the food needs of the household family (Bubenko and Rastjapin, 2002; Olenych et al., 2012).

Each agricultural enterprise in its activities, as a rule, seeks to realize one of two goals:

-maximization of profit from activity;

-maximizing the value of the enterprise.

It should be noted that in maximizing of the enterprise value are interested those owners who in the near future can profitably sell it.

The directions of activity of an agricultural enterprise are defined both economic and social aspects, and the separation of economic content from the social (social) can not be justified. Each such enterprise can be considered as a set of certain functions related to agricultural production. The significance of such functions is important, since each of them has the ability to influence the realization of the goals of the enterprise.

The expediency of considering in particular the social functions of an enterprise is determined by the Constitution of Ukraine, many other legislative and regulatory acts that indicate the creation of a socially oriented market economy in Ukraine. An agricultural enterprise, besides production, satisfies public needs, using the mechanism of competition. An agricultural enterprise must be perceived as seeking to achieve its goals through the market. The economic efficiency of an agricultural enterprise is a reflection, on the one hand, of skilful entrepreneurial activity, and on the other - cooperation with partners.

From the theory of the economic system, it follows that an agricultural enterprise is a system and at the same time a subsystem, such as the organization of agricultural production. The agricultural enterprise - the system is open and very complex in view of the allocation in it of three subsystems: social, economic and natural. The 
peculiarity of agricultural enterprises and the problem is that their value is estimated predominantly in the economic area, without taking into account social and natural.

Such an approach to determining the criteria creates favorable conditions for replacing the domestic resources of agricultural enterprises with capital and the introduction of new technologies on the basis of widespread attraction of financial resources and means of production.

Among the many functions of an agricultural enterprise and entrepreneurial activity that perform simultaneously the role of subsystems, particular importance are:

1) management of natural resources;

2) management of land resources;

3) management of labor resources.

Under the production process in an agricultural enterprise it is necessary to understand conscious and targeted entrepreneurial activity with means of labor and use of resources of the natural environment in order to change the properties (physical, chemical, biological) or the state of the subject of labor, which makes it possible to obtain a useful agricultural value in the form of those which are satisfied with mediation or directly to social needs, which makes it possible to obtain a useful agricultural value in the form of those who are satisfied with mediation or directly to social needs. Since such market principles of agriculture in agriculture, which dominate outside the enterprise penetrate into its internal environment, it can be argued that satisfaction of public needs for agrarian products takes place through the food market with a very high level of competition.

Entrepreneurship in agricultural production is subordinated to the following objectives:

1)the definition and establishment of conditions that ensure the optimal use of financial, labor and natural resources, land and management of agricultural production;

2) determining a possible deviation of the actual use of resources from the optimal;

3) the study of determinants influencing the structure of production and use of resources;

4) 1) the formation of specific means and methods of transition from the current state of using resources to the optimal.

The situation in which the subject of entrepreneurial activity in agriculture can be characterized by a combination of certain possible actions, among which one can make a choice; a set of possible states of the environment that can not be controlled by such a subject; combination of consequences which is the result of making certain decisions for the current state of the environment; a subjective approach to the expected benefit.

Subjects of entrepreneurial activity in agriculture are not static units, but subject to constant changes caused by internal factors and external factors.

All factors affecting both agrarian production and forms of entrepreneurial activity can be divided into conditional on macro- and microeconomic ones.
Budgetary, tax, foreign economic, monetary, economic and food security of the country, etc. should be attributed to the macroeconomic. Globalization factors, which primarily determine the parameters of agricultural activity of enterprises, and, accordingly, the form themselves of entrepreneurial activity are of particular importance. Most of them are of particular importance today due to Ukraine's membership in the WTO and the signing of an association agreement with the European Union, which determines the foreign economic policy of the country regarding the agro-food market.

Regional factors for the development of entrepreneurial activity in agriculture have one of the key influences precisely for agricultural production under certain conditions (climate, soils, location, social sphere, infrastructure). Microeconomic problems include problems of land relations, insolvency of agricultural producers, the financial crisis of the agricultural sector and a number of others. Today, the practice of production and commercial activity of business entities in agriculture convinces, that the most effective in solving ecological problems of nature use is the regional level. In our opinion, the greatest attention of researchers needs such directions as ecological expediency of nature management, ecologization of agricultural production, methodology of ecological and economic zoning; organization of environmental studies by subjects of the infrastructure of the agrarian sector.

The main subjects of entrepreneurial activity engaged in the production of agrarian products, processing of own produced agricultural raw materials and their implementation, are agricultural commodity producers of all forms of ownership and organizational and legal forms of management, among which the leading role belongs to agricultural enterprises. They include: state agricultural enterprises, agricultural production cooperatives, business associations, private farms, agricultural companies, farms, as well as joint (with foreign investments) agricultural enterprises, agroholdings (Smolynec, 2011).

Since the main goal of state enterprises is the realization of state policy, they must have high production potential, use modern industrial technologies. Most of them are in full state funding. At the same time, it is inappropriate to create state-owned agricultural enterprises of the traditional type.

For a long time, on the basis of the former collective farms operated SSP (CCП). Collective and cooperative agricultural enterprises are, above all, enterprises transformed from former collective farms, but at the same time their economic management mechanism is based on the rights of the peasants to own land and property. Their advantage is the preserved and developed production structure, to a certain extent the fairness of the distribution of profits between members on a parity basis. However, these farms today are left alone.

Agro-industrial associations became new organizational forms that appeared in modern conditions and which combine agricultural and industrial enterprises. This is the so-called form of vertical integration of enterprises that specialize in several or one type of agricultural product, grow it and recycle this product. Such integration is characterized by new forms of labor 
organization and increase of efficiency of agricultural production and entrepreneurial activity in particular.

Societies are another large group of companies. They may be limited liability, additional or full, corporate or joint stock companies. Their purpose and functioning is regulated by the Commercial Code of Ukraine and other special legislative acts.

The most commonly used in the domestic agrarian sector of the economy are commodities with limited liability. Here, the founders of production agricultural cooperatives have a certain number of owners of property and land. The rest of the property and land are leased on the relevant contractual terms.

There are also joint-stock companies. The fundamental difference between them and other companies is that the exit from such associations of shareholders is possible only if all their shares are sold not at nominal value, but profitability of a joint-stock company, but they can not claim the property and land they have been handed over to them.

Limited form of entrepreneurial activity in agriculture are limited partnerships. Here, a certain number of participants fully assumes the decision on all issues of the company's business, while answering for the debts of the company as their shares in the statutory fund, as well as personal property. And other members of such a society are responsible for its debts only the share in the statutory fund. On this basis, they do not take part in the management of the enterprise. At a meeting of participants, they have the right only an advisory vote.

Another organizational and legal form of enterprises is private, which can also enter into lease relations. Owners of such enterprises can lease land and property to other peasants with the obligatory conclusion of a contract, where the amount of the rent for property and land and the rights and obligations of the parties are indicated.

One of the most common organizational forms of entrepreneurial activity in agriculture in Ukraine is the farming sector. Mostly this is a form of family economy, which at the same time acts as a primary social link, and a primary link in social production. This ensures a high level of stability and stability.

As the world practice shows, the most effective model of peasant farms are farms with large size farmland, equipped with a full range of machines and agricultural machinery, who are fully and precisely following the main technological operations and are usually headed by specialists with agrarian education and experience in agriculture (Donec, 2011).

Agricultural enterprises, as well as any other business entities, are classified in size to small, medium and large. According to O. Borodina and I. Prokop, the very small and medium forms of farming combine the production of agricultural products with the production of public goods (reproduction of the peasantry, preservation of agrolandshafts, etc.) (Borodina, 2008). In recent years, for example, development has begun, in particular, joint ventures created on the basis of capital investments of domestic and foreign partners, which jointly carry out entrepreneurial activity, management and distribution of profits. Such enterprises are quite large in size and have mostly a holding type of activity.
Households are the primary form of organization of production of agricultural products, employment of peasants and a source of additional (and sometimes even unified) incomes, which provide full satisfaction of material, residential, cultural and household needs of rural families.

In the domestic agrarian literature and practice, there is no unity about the nature, organization of households and the prospects for their development. In general, there are three approaches to this problem:

1. The existence of households is a prerequisite for the formation of a market economy in the countryside, which requires their development;

2. Inappropriate formation of such farms in the village due to their low efficiency;

3. Change and streamline the process of organization and development on the basis of the formation of the appropriate mechanism.

An approach to the classification of forms of entrepreneurial activity in agriculture in relation to their size is interesting. There are five types of them. These are agricultural holdings that handle tens and hundreds of thousands of acres of land, large-scale agricultural producers, who handle from three to ten thousand hectares, average commodity producers, which process several thousand hectares, farms, in the cultivation of which there are several hundred hectares, and farms with one to two hectares of land (Zubec and Bezuglyj, 2010).

We support the opinion of some authors that the organizational foundations of existing agro-formations should be based, first of all, on increasing the interest of owners in joint activities on the principles of collective labor organization. The priority is the formation of such an economic mechanism, which would fully correspond to the market conditions of management, business, .provision of expanded reproduction, constant growth of welfare of agricultural workers.

As it follows from the research, it is necessary to describe the current state of production in the field of agriculture, find a place for different forms of entrepreneurial activity in the general balance of production of the industry, build its desired structure for the future until 2015-2020, depending on the complexity of the transition period and taking into account international standards of product quality, and thus outline concrete measures for changing the forms of economic entities. At the same time, it can be assumed that such restructuring of agriculture can strengthen the monopoly of individual forms of entrepreneurial activities and their separate entities in the regional market, weakening competition with all negative consequences for the growth of agricultural production efficiency.

Undoubtedly, in the process of transformation of the structural construction of domestic agricultural production, it is compulsory to take into account the world experience and achievements of foreign scientists. As T. Ostashko notes, after a radical structural reform in transition economies, a bimodal structure of economic entities with a different share of large enterprises and small and medium-sized farms has developed. Farmers predominate in the structure of agricultural lands of Albania, Slovenia, Latvia, Romania. In Lithuania, 
Bulgaria and Estonia, farms and households together account for more than half of agricultural land. In Slovakia, Hungary, the CIS countries and the territory of the former German Democratic Republic dominate large farms (Ostashko, 2004). By the number of most «enterprises of self-management peasants». In terms of land use - the largest economic partnerships.

According to L. Moldavan, the intensification of competition has led to the need to increase land and crop rotation, the use of new technology and technology, reducing individual costs for the creation of material and technical base in order to strengthen the economic situation and ensure the competitiveness of production. This necessity induces farmers to join such collective organizational and legal forms, which, on the one hand, preserve as far as possible the advantages and principles of functioning of farms, and on the other hand, they realize the advantages of a large economy in the issues of mechanization, maintenance, intensification and form the effect of co-operation (Moldavan, 2010).

\section{Conclusions}

Consequently, the modern development of production associations (societies) is characterized by the use of such legal forms that retain the basic characteristics of the family farm and at the same time create favorable conditions for the organization of production structures adequate to large enterprises, family transfer of farms. That is, the collective forms of farm activity perpetuate the personal and seminal nature of agriculture, prevent the proletariat of the peasantry, retain its status as the owner of the rural territory. It is these trends in the formation of entrepreneurial activity in agriculture, taking into account domestic realities, to be taken into account in the development of the pre-restructuring and transformation of domestic agrarian production.

A typical farmer, even when he has a small family farm, combines an investor, manager and manager in it. In somewhat larger structures, such as family farms, one may also be an accountant, an organizer of work, a plant and animal care specialist, a mechanic, etc. On successful business activity, in our opinion, it is possible to speak, if:

1) the enterprise has income for payment of all necessary expenses;

2) the enterprise has additional income necessary to pay the loans that may be invested;

3) the production capacity of the enterprise and its potential are not reduced, but desirable - are developing.

Compliance with these conditions can be one of the important reasons for the successful development of entrepreneurial activity.

Despite certain advantages or disadvantages of individual forms of entrepreneurial activity, it is necessary to develop various organizational and legal forms in agriculture in market competitive conditions. But it is necessary to take into account, that social changes affect the system of organizational, economic and legal relations in agriculture. Subjects of entrepreneurial activity, operating today in agriculture, functioning on the basis of different forms of ownership, not only have the right to exist, but also, competing with each other, create conditions for the development of market relations, profitable agricultural production.

In general, it should be recognized that the development of forms of entrepreneurial activity in agriculture will determine the totality of changes in regional, national and global character and proceeding from this, it is important to determine the aspects of the development of various organizational and legal forms of entrepreneurial activity.

\section{Бібліографічні посилання}

Borodina, O. (2008). Agrarna polityka Ukrai'ny: vytoky, suchasnyj stan i novi mozhlyvosti $v$ konteksti instytucionalizmu ta vyklykiv globalizacii'.Ekonomika Ukrai'ny. 10, 94-111 (in Ukrainian).

Bubenko, I., Rastjapin, A. (2002). Pro metody ocinky efektyvnosti investycijnyh proektiv. Ekonomika Ukrai'ny. 8, 80-83 (in Ukrainian).

Gubeni, Ju.E. (2001). Transformacija sil's'kogospodars'kyh kooperatyviv v Ches'kij respublici i Pol'shhi: konceptual'nyj pidhid i pryncypy i'i' zdijsnennja / Visnyk Poltavs'kogo derzhavnogo sil's'kogospodars'kogo instytutu. 5(6), 97-100 (in Ukrainian).

Donec', O.V. (2011). Organizacijni formy gospodars'koi' dijal'nosti u sil's'komu gospodarstvi. Naukovyj visnyk Uzhgorods'kogo universytetu. 33(1), 97-101 (in Ukrainian).

Zubec', M.V., Bezuglyj, M.D. (2010). Ekonomichni aspekty reformuvannja agrarno-promyslovogo kompleksu Ukrai'ny. Nacional'na akademija agrarnyh nauk Ukrai'ny. K.: Agrarna nauka (in Ukrainian).

Moldavan, L.V. (2010). Formy gospodarjuvannja V agrarnomu sektori Ukrai'ny v umovah globalizacii'. Ekonomika APK. 1, 13-17 (in Ukrainian).

Olenych, I.R. Hariv I.I., Gutyj B.V. (2012). Osoblyvosti segmentuvannja rynku veterynarnyh preparativ [Elektronnyj resurs]. Naukovyj visnyk L'vivs'kogo nacional'nogo universytetu veterynarnoi' medycyny ta biotehnologij im. G'zhyc'kogo. 14, 1(2), 113-116 (in Ukrainian).

Olenych, I.R. Grymak, O.Ja., Gutyj, B.V., Hariv, I.I., Smolynec', I.B. (2013). Sutnist' i cili mizhnarodnogo farmacevtychnogo marketyngu [Elektronnyj resurs]. Naukovyj visnyk L'vivs'kogo nacional'nogo universytetu veterynarnoi' medycyny ta biotehnologij im. G'zhyc'kogo. 15, 1(5), 127-132 (in Ukrainian).

Olenych, I.R. Dushka, V.I., Myhajlovs'kyj, V.I., Hariv, I.I., Seniv, R.V., Gutyj, B.V. (2011). Suchasna polityka zbutu $\mathrm{V}$ zovnishn'oekonomichnij dijal'nosti farmacevtychnyh pidpryjemstv. Naukovyj visnyk L'vivs'kogo nacional'nogo universytetu veterynarnoi' medycyny ta biotehnologij im. G'zhyc'kogo. 13, 1(1), 444-447 (in Ukrainian).

Olenych, I.R., Gutyj, B.V., Hariv, I.I., Shybun'ko, V.V. (2012). Formuvannja kompleksu marketyngu vitchyznjanogo vyrobnyka veterynarnyh preparativ [Elektronnyj resurs]. Naukovyj visnyk L'vivs'kogo nacional'nogo universytetu veterynarnoi' medycyny ta biotehnologij im. G'zhyc'kogo. 14, 1(2), 53-61 (in Ukrainian). 
Ostashko, T.O. (2004). Rynkova transformacija agrarnogo sektora. K.: Feniks (in Ukrainian).

Smolynec', I.B. (2011). Organizacijno-ekonomichni zasady funkcionuvannja agrarnogo sektora umovah transformacijnoi' ekonomiky. Naukovyj visnyk L'vivs'kogo nacional'nogo universytetu veterynarnoi' medycyny ta biotehnologij imeni S. Z. G'zhyc'kogo. L'viv. 13, 1(47), 250-254 (in Ukrainian).

Smolynec', I.B., Garasymljuk, M.V. (2014). Organizacijno-pravovi formy pidpryjemnyctva. Naukovyj visnyk L'vivs'kogo nacional'nogo universytetu veterynarnoi' medycyny ta biotehnologij imeni S. Z. G'zhyc'kogo. L'viv, 16, 1(58), 94-100 (in Ukrainian).
Smolynets,' I.B., Gutyj, B.V., Khariv, I.I., Petryshak, O.Y., Lytvyn, R.I. (2016). Pharmaceutical marketing: objectives and types. Scientific Messenger LNUVMBT named after S.Z. Gzhytskyj, 18, 2(69), 151-154.

Smolynets, I., Gachek, T., Dorosh-Kizym, M., Dadak, O., Gutyj, B., Hariv, I. (2016). Sutnist, funktsii ta formy pidpryiemnytskoi diialnosti v silskomu hospodarstvi. Scientific Messenger LNUVMBT named after S.Z. Gzhytskyj, 18, 2(69), 141-150 (in Ukrainian).

Received 31.08.2017 Received in revised form 26.09.2017 Accepted 2.09.2017 